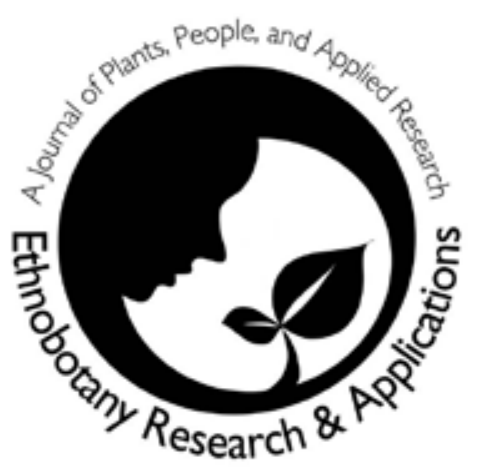

\title{
The Transplanted Peruvian Culture in Rome: An assessment through images
}

\author{
Yarissa K. Matos-Soto and Valentina Savo
}

\author{
Photo Essay
}

\begin{abstract}
Peruvian immigrants in Rome represent a large community, creating microcosms where people retain strong interpersonal and family bonds. The aim of this photo essay is to portray, through images, some of the transplanted cultural aspects of Peruvians in Rome and to define the ethno-botanical uses of plants that are still present. An ethno-botanical study was carried out during Spring and Summer 2011 in the city of Rome with Peruvian migrants established in Italy for at least 10 years. We used a snowball sampling approach visiting local markets, rrestaurants and churches, performing semi-structured interviews about uses of medicinal and food plants. We looked for the presence of culturally important plant species, taking note of the maintenance, replacement, incorporation and discontinuation of ethno-botanical uses. A total of 21 informants were interviewed reporting the uses of medicinal and food plant species still present in Rome. Many plants are still used for medicinal (38 species) or food purposes (35 species), while fewer plants are used as nutraceuticals (7 species). Medicinal uses described are, sometimes, associated with rituals and spiritual convictions. The relatively high number of food species still present in Rome could be interpreted by the fact that they are more easily accessible and that some are cultivated in Italy. However, informants generally prefer plants that originate from Peru even if sometimes they found fault about the quality of imported plants. Peruvian immigrants were found to attempt to adhere to their cultural identity, in the use of plants, trying to conserve their pre-migratory traditions as much as they can.
\end{abstract}

\section{Abstracto}

Los migrantes peruanos en Roma representan una gran comunidad, creando un micro-cosmos, donde las personas mantienen fuertes lazos interpersonales y familiares. El objetivo de este ensayo fotográfico es mostrar, a través de las imágenes, algunos de los aspectos culturales de los peruanos trasplantados en Roma y definir los usos etnobotánicos de las plantas que aún están presentes. Una investigación etnobotanica se llevó a cabo durante la primavera y el verano del 2011 en la ciudad de Roma con migrantes peruans, establecida en Italia desde al menos 10 años. Se utilizó un método "snowball" para visitar los mercados locales, restaurantes y iglesias, las. Los entrevistas fueron semi-estructuradas sobre plantas medicinales y alimentos. Buscamos la presencia de especies vegetales de importancia cultural, teniendo en cuenta el mantenimiento, sustitución, incorporación y abandono de los usos etnobotánicos. Un total de 20 informantes fueron entrevistados sobre los usos de especies de plantas medicinales y los alimentos que siguen presentes en Roma. Muchas plantas se siguen utilizando como medicina (38 especies), alimentos (35 especies), mientras que un menor número de plantas se utilizan como nutriceuticas (7 especies).

\section{Correspondence}

Yarissa K. Matos-Soto, Biology Department, Rollins College, 1000 Holt Ave. Winter Park, Florida 32789 U.S.A.

Valentina Savo, Environmental Biology Department, University Roma Tre, Viale Marconi, 446, 00146, Rome, ITALY.

vsavo@uniroma3.it

Ethnobotany Research \& Applications 10:095-108 (2012)

Published: April 11, 2012 
A veces, los usos medicinales están asociados con los rituales y las convicciones espirituales. El numero relativamente elevado número de especies de los alimentos podría ser interpretado por el hecho de que son más fácilmente accesibles y que algunas de esta plantas se cultivan en Italia. Sin embargo, los informantes en general, prefieren las plantas que se originan en Perú, aunque a veces se encontraron fallas en la calidad de las plantas importadas. Los migrantes peruanos se encontraron para tratar de mantener su identidad cultural, en el uso de las plantas, tratando de conservar sus tradiciones pre-migratorias tanto como les sea posible.

\section{Riassunto}

Gli immigrati peruviani che vivono a Roma rappresentano una vasta comunità, creando una serie di micro-cosmi al cui interno le persone mantengono forti legami interpersonali e familiari. Gli scopi di questa documentazione fotografica sono quello di ritrarre, attraverso immagini, alcuni aspetti della cultura peruviana trapiantata a Roma e di definirne gli usi enobotanici ancora presenti. Una ricerca etnobotanica è stata svolta nel periodo estivo-primaverile del 2011 nella città di Roma con immigrati peruviani residenti in Italia da almeno 10 anni. E' stato utilizzato l'approccio "palla di neve" facendo sopralluoghi in mercati locali, ristoranti, chiese, ecc. utilizzando interviste semi-strutturate su usi di piante medicinali e alimentari. Abbiamo documentato la presenza di piante culturalmente importanti, prendendo nota sulla della conservazione, sostituzione, introduzione e discontinuità degli usi etnobotanici. Un totale di 21 informatori sono stati intervistati ed è stato possible annotare gli usi di piante medicinali e alimentari che sono ancora praticati a Roma. Molte piante sono utilizzate per scopi medicinali (38 specie), alimentari (35 specie) mentre un numero inferiore di piante sono usate come nutraceutici (7 specie). A volte, gli usi medicinali sono associati a rituali e convinzioni spirituali. II numero relativamente alto di specie alimentari può essere dovuto al fatto che esse sono facilmente reperibili e che alcune sono coltivate anche in Italia. Comunque, gli informatori generalmente prediligono le piante che vengono dal Peru, anche se a volte hanno espresso commenti negativi sulla qualità delle piante importate. E' stato evidenziato che gli immigrati peruviani cercano di aderire alla loro identità culturale nell'uso delle piante, cercando di conservare quanto più possibile le loro tradizioni originarie.

\section{Introduction}

Migration allows cultures to expand, integrate, isolate, or disappear once members adopt/reject habits and ideas of the new ethnic society (Green et al. 2006). It has been found that plant knowledge travels with migrating human groups and that the exposure to different societies and resources may lead to cultural evolution (Pieroni \& Vandebroek 2007). Recently, there has been an increase in ethnobotantical and ethnomedicinal investigations about plant knowledge in relation to migrant groups (Van Andel et al. 2010). However, few studies have been conducted with Latin American migrants (e.g., Ceuterick et al. 2008; Ceuterick et al. 2011) and basically none with those living in Italy. Over the last centuries, various migrant populations have established themselves throughout Italy bringing along their culture and ethnobotanical knowledge: Graecanic (eighth century BC) and Albanian (fifteenth century AD) people in Southern Italy (Nebel et al. 2006, Pieroni et al. 2002a,b, 2005) or the Tabarkins (18th century AD) in Sardinia (Maxia et al. 2008).

About $7.0 \%$ of the total residents in Italy are documented foreigners with numbers at 4,279,000 (ISTAT 2010). We decided to focus our interest on Latin Americans since the population is predominantly "mestizo" or racially mixed with origins from various ethnic groups: e.g., European and native populations. In Italy, one of the leading Latin American representatives are Peruvians with a population of 85,000 (ISTAT 2010) with a well-established community and an extensive concentration of migrants based in Rome (about 12,000). Peruvian migrants were found, according to other authors, to have a strong cultural background and connection to their country in other European cities (Ceuterick et al. 2011), so we wanted to test whether the same findings (behaviors, patterns, traditions) were extended to Rome.

Peruvian origins can be traced back to the ethnic groups of the Quechua, the Aymara, and Amazonian natives, which later intermixed with the Spanish conquistadors (Hudson 1992). In the historical context, Peru has gone through several phases that have brought drastic changes in its economy, society and politics. The most influential change was the Spanish invasion and conquest in 1532 that uprooted and altered the Peruvian's way of living. Even with numerous adverse occurrences, the Peruvian people have remained resilient and strong-willed with a courageous attitude. The diversity, color, and traits of $\mathrm{Pe}-$ ruvian's folklore, art and cultural identity are ways of life shared with Peruvian communities throughout the world maintaining strong native cultural traditions intricately mixed with facets of Inca beliefs and Roman Catholicism (Hudson 1992).

The land of Machu Picchu, llamas and vibrant ponchos are the images that flood our minds when thinking of Peru. These are images that make Peru different from other Latin American countries; the Peruvian culture is complex and not homogenous. Peruvians are separated by ethnic loyalty and identity connecting with stereotypes of certain social groups or regions, yet retaining strong ties to the Inca tradition and culture. In Rome, you feel the presence 


\section{Matos-Soto and Savo - The Transplanted Peruvian Culture in Rome: An assessment through images}

of Peruvian culture in the late Sunday afternoons with gatherings in the parks, listening to the exotic Latin beats and the smell of fresh homemade dishes. You can see the children assembled to listen to stories and myths about Peru told by grandparents. These myths put in perspective the surviving connection with the Incas that carries over with the food and medicinal plants still used.

The aim of this photo essay is to depict some of the transplanted cultural aspects of Peruvians in Rome and their ethnobotanical uses of plants still present. Observations and results obtained were documented during the research by a series of photos. The present photo essay is based on different locations in the city of Rome, showing informants, plants, settings and cultural behaviors.

\section{Methods}

Photographs transmit messages, convey complex information and assist in illustrating a visual context of research aims (McClatchey et al. 2005). Here, the images will provide an insight of how ethnobotanical culture of $\mathrm{Pe}$ ruvians has continued to thrive in another country.

\section{Ethnobotanical survey}

During Spring and Summer 2011, visits were made to areas of Rome that had a Peruvian presence to study plants still used by migrants, reflecting their importance through cultural value. Information was collected using a snowball method performing semi-structured interviews that were conducted in Spanish and Italian (Castillo 2009).

The study included visits to local Peruvian restaurants, multi-ethnicity fresh food markets, churches, assembling points, and informant's homes within Rome in the areas of Esquilino, Centocelle, Piazza Vittorio Emanuele, Castro Pretorio, Piazza Repubblica, and Piazza Mancini.

A total of 21 interviews (Figure 1) were performed with Peruvian migrants who have been living in Rome for at least 10 years and still use at least three traditional $\mathrm{Pe}-$ ruvian plants for food or medicinal purposes. Informants were made aware of the scope of the research and interviews were carried out following the International Society of Ethnobiology Code of Ethics (ISE 2006).

The majority of plants mentioned by the informants were identified using different floras (Maas \& Westra 1993, Pignatti 2003, Smith et al. 2004, Walters et al. 1986-2000) and the online herbarium collection of the New York Bo-

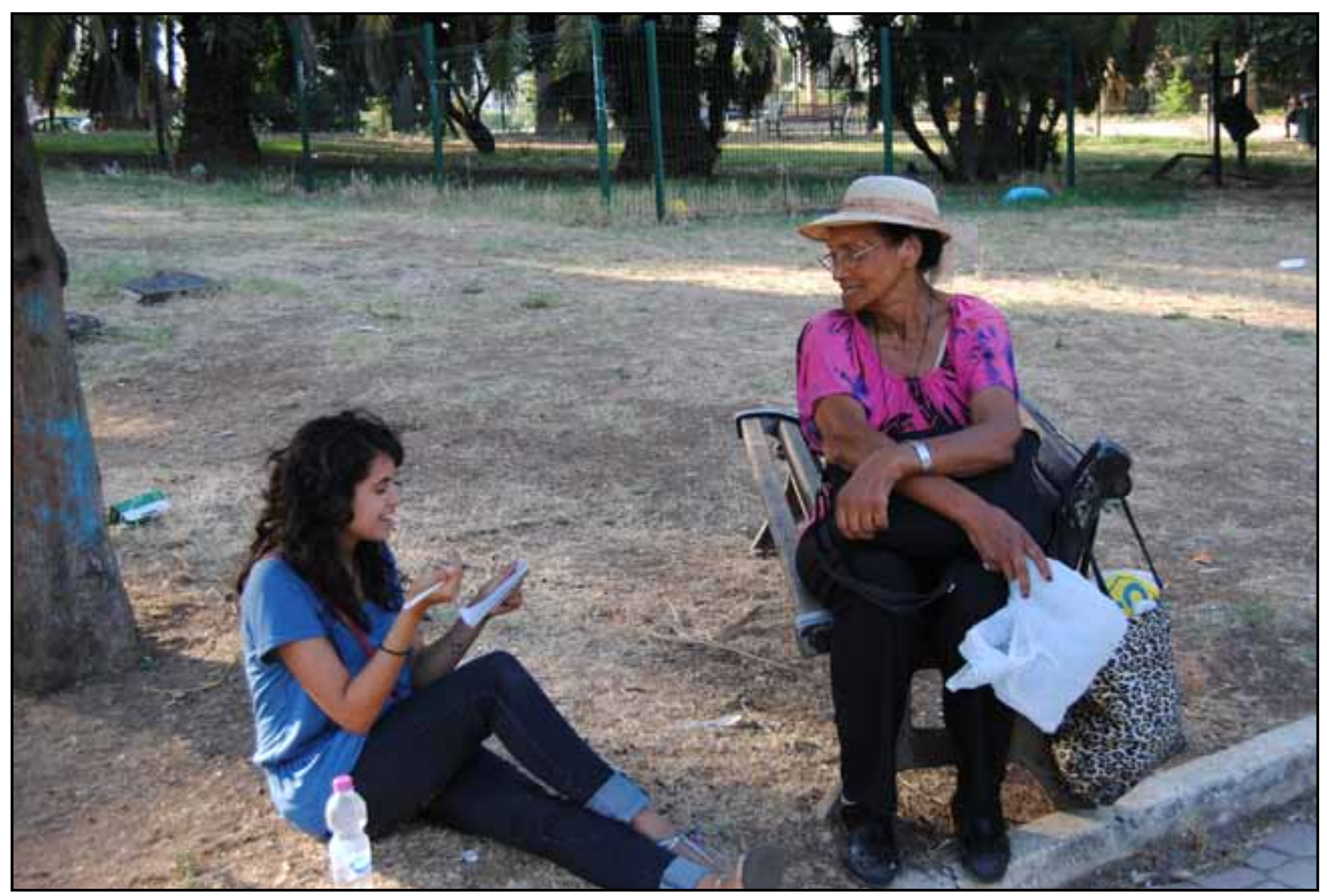

Figure 1. The first author conducting a semi-structured interview with a Peruvian informant at Piazza Mancini, Rome, Italy. 
tanical Garden (NY) defining the species at varietal level, while some plants have been identified only at the species or genus level (due to the fact that some materials were only plant fragments). Their scientific names were updated using international databases (ThePlantList 2011, TROPICOS 2011). Voucher specimens are deposited at University Roma Tre Herbarium (URT) (Thiers 2011).

\section{The camera and the photos}

Photos were only taken after the Prior Informed Consent (Johnson et al. 2010) was obtained verbally. Documentation was made in the form of photos using three different digital cameras: Nikon D40, Kodak EasyShare C143, and Nikon D3000.

\section{Results and Discussion}

Throughout the study, we recorded 63 species that are still used by Peruvians in Rome. It was found that the Peruvian culture in Rome maintained independence from Italian culture with a well-connected social network with weekly casual gatherings (Figure 2). These gatherings have become a way to maintain their identity to interact with others that understand their way of thinking and hab-

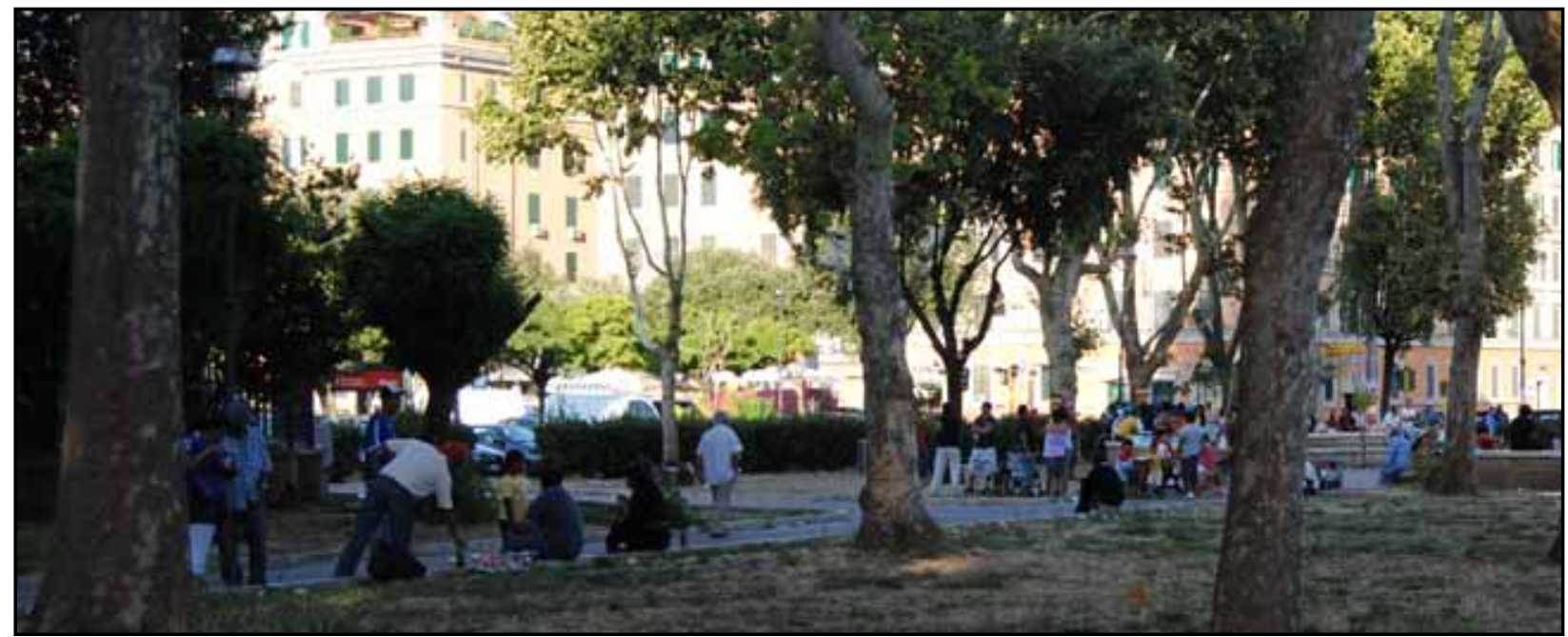

Figure 2. Peruvians meet in Rome during certain days of the week in specific places, where they talk, eat and listen to the music.

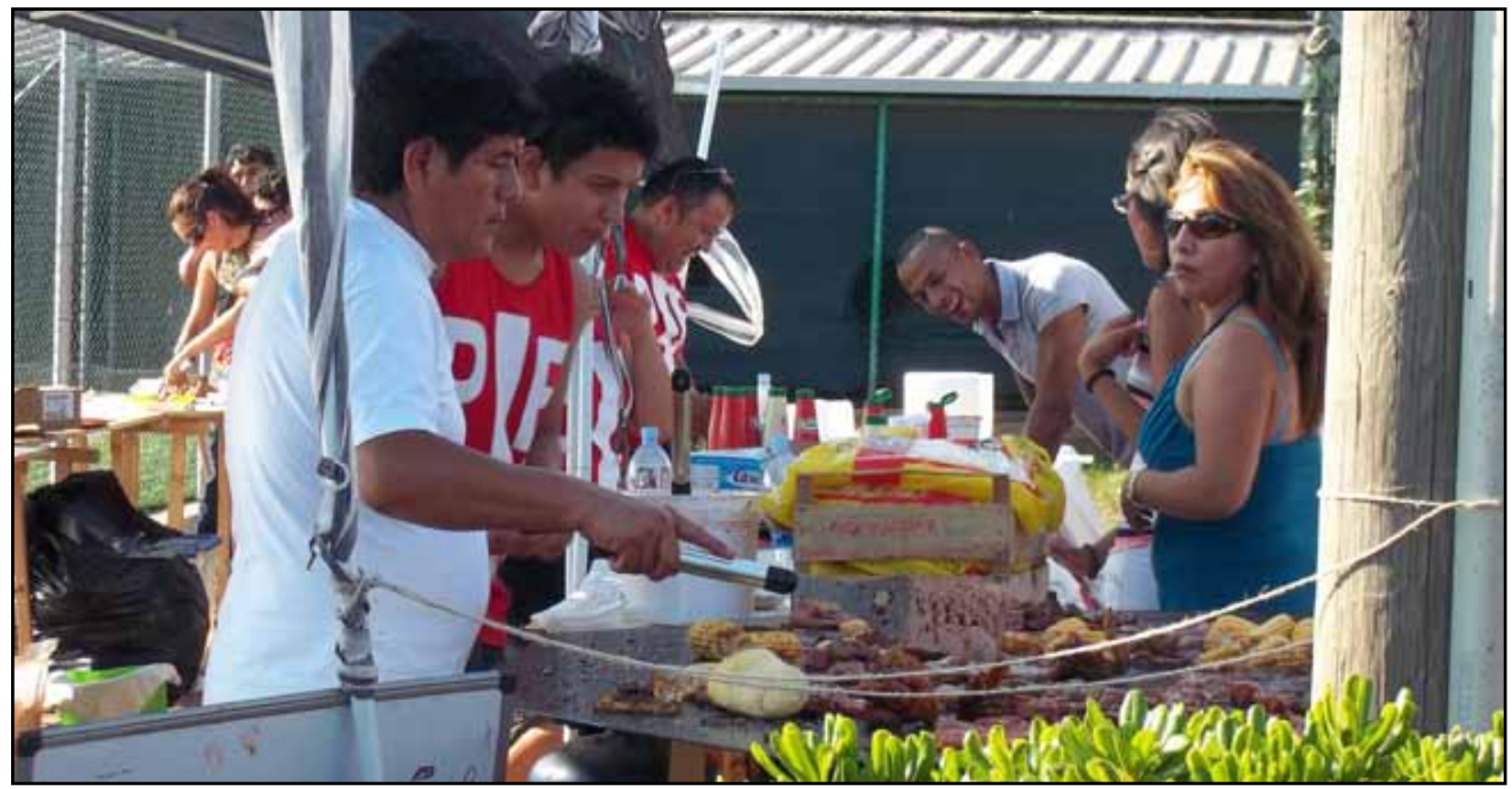

Figure 3. Celebration of the Anniversary of Independence of Peru, in Rome (July, 2011). Festivals with traditional food, dances and games were held in different locations in the city. 


\section{Matos-Soto and Savo - The Transplanted Peruvian Culture in Rome: An assessment through images}

its; they can eat Peruvian food (maize, habas, and ceviche) and listen to Latin music. There are also numerous celebrations and festivals that are held through the year (Figure 3). The effectiveness of a snowball method can be seen by how many of the informants $(100 \%)$ referenced sources of where we could find more Peruvian informants, demonstrating the presence of strong inter-culture bonds.

There were a limited number of locations to find informants and plants of Peruvian culture. The most cited location of where imported Peruvian food and medicinal plants could be obtained was an open-air market near Piazza Vittorio Emanuele. Several market stalls (Figure 4) dedicated to South American customers were found to sell many plants imported from Peru. We found bags of dried medicinal plants (Figure 5) containing mixtures or single plant species (some of these plants grow also in Italy, nevertheless, they are imported from Peru): e.g., Peumus boldus Molina, Linum usitatissimum L., Hordeum vulgare L., Ruta graveolens L., Matricaria chamomilla L., Uncaria tomentosa (Willd. ex Schult.) DC., Mentha x piperita L. Vendors also sold Peruvian imported fruits, aromatic herbs (Figure 6) and vegetables (Figure 7) (e.g., Annona muricata L., Mangifera indica L., Capsicum baccatum var. pendu- lum (Willd.) Eshbaugh) and dried crops (e.g., papa seca: Solanum tuberosum L.). Worldwide used plants, such as Rosmarinus officinalis L., Foeniculum vulgare Mill., Ocimum basilicum L., and Laurus nobilis L. (Figure 8) could be obtained in a more versatile range of locations.

Other options for obtaining Peruvian plants may be by visiting friends or relatives from Peru or cultivation on balconies or home-gardens (Figure 9).

The most cited (52\% of informants) reason for not using medicinal or food plants in Italy was "No hay aqui" which means "(the plants) are not here." Informants reported that it is not easy to get plants from Peru or obtain permits to import them; also they are generally expensive. Therefore, the fact that to obtain these plants requires a certain effort could support the reasoning that these plants are important species for Peruvian culture. Among these, the most cited medicinal plants (the first five) found in Rome were: Aloe vera (L.) Burm f., M. chamomilla, Erythroxylum coca Lam., R. graveolens, and Peumus boldus Molina (Figure 10). In a similar study conducted in London, among the ten most cited plants by Peruvian migrants there are M. chamomilla, A. vera, and E. coca (Ceuter-

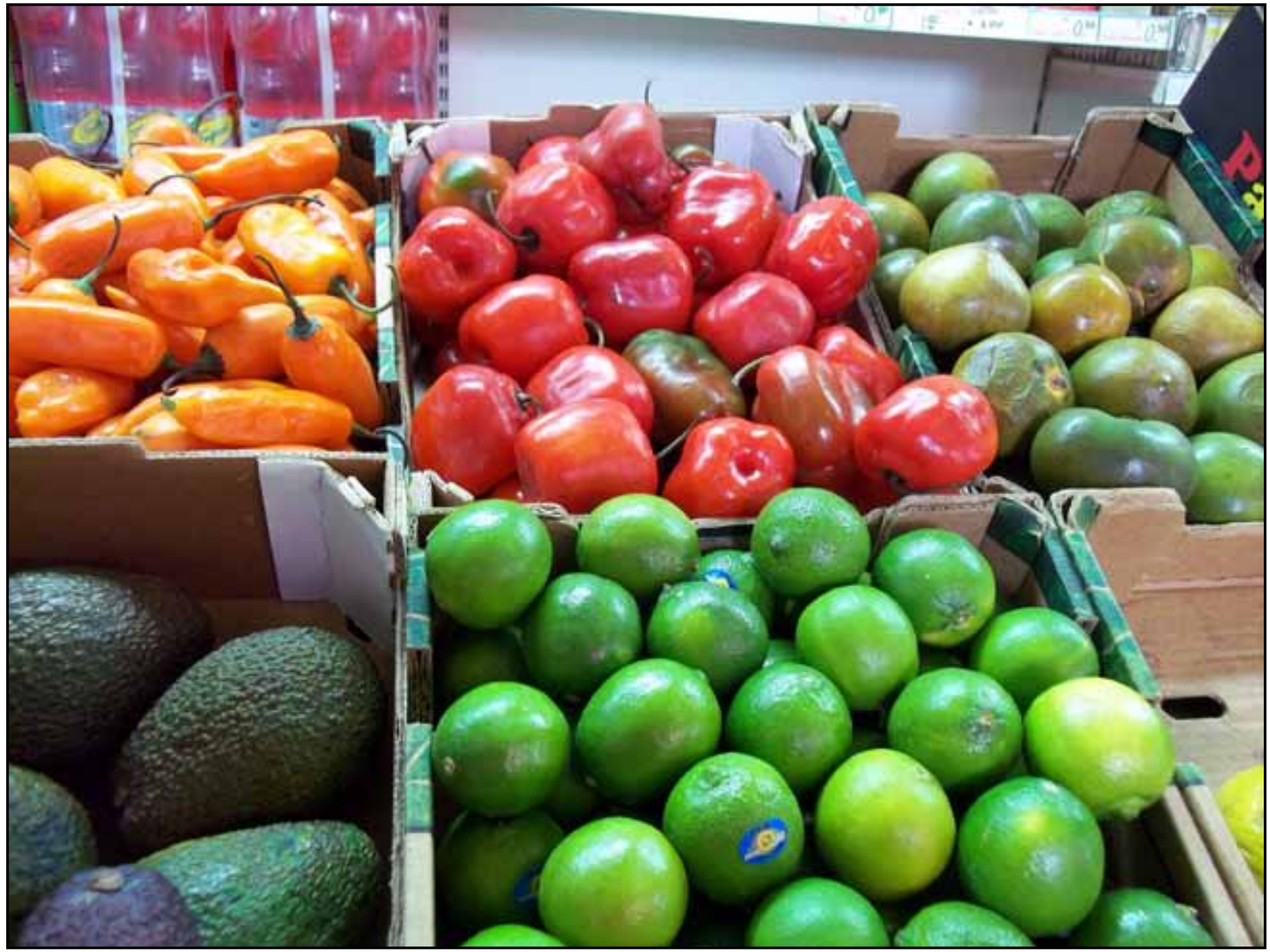

Figure 4. Market stall with fruits and vegetables imported from South America (mainly from Peru), in Rome, Italy. 


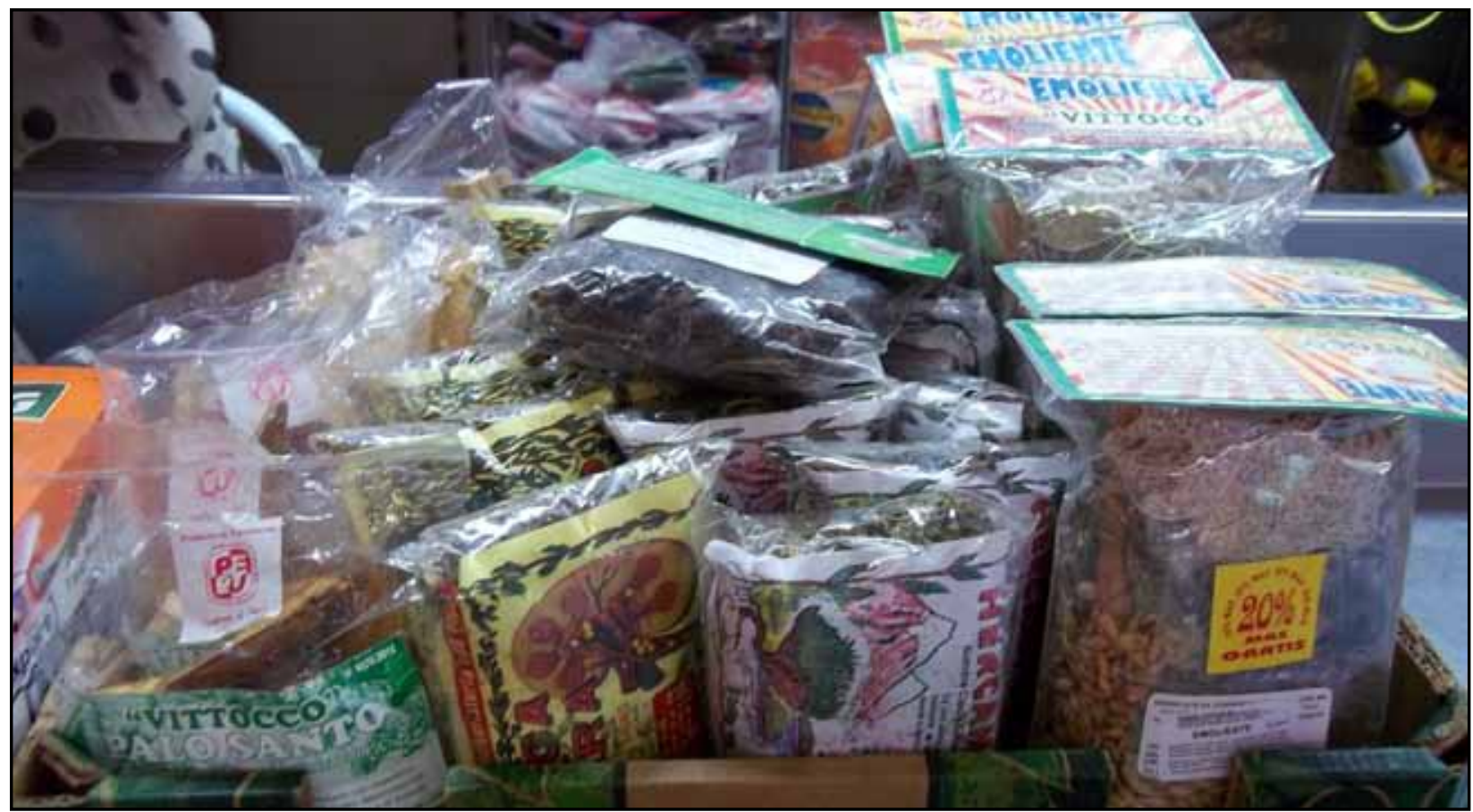

Figure 5. Dried medicinal plants imported from Peru. Many of these mixtures are well known by informants and are often added to more complex preparations.

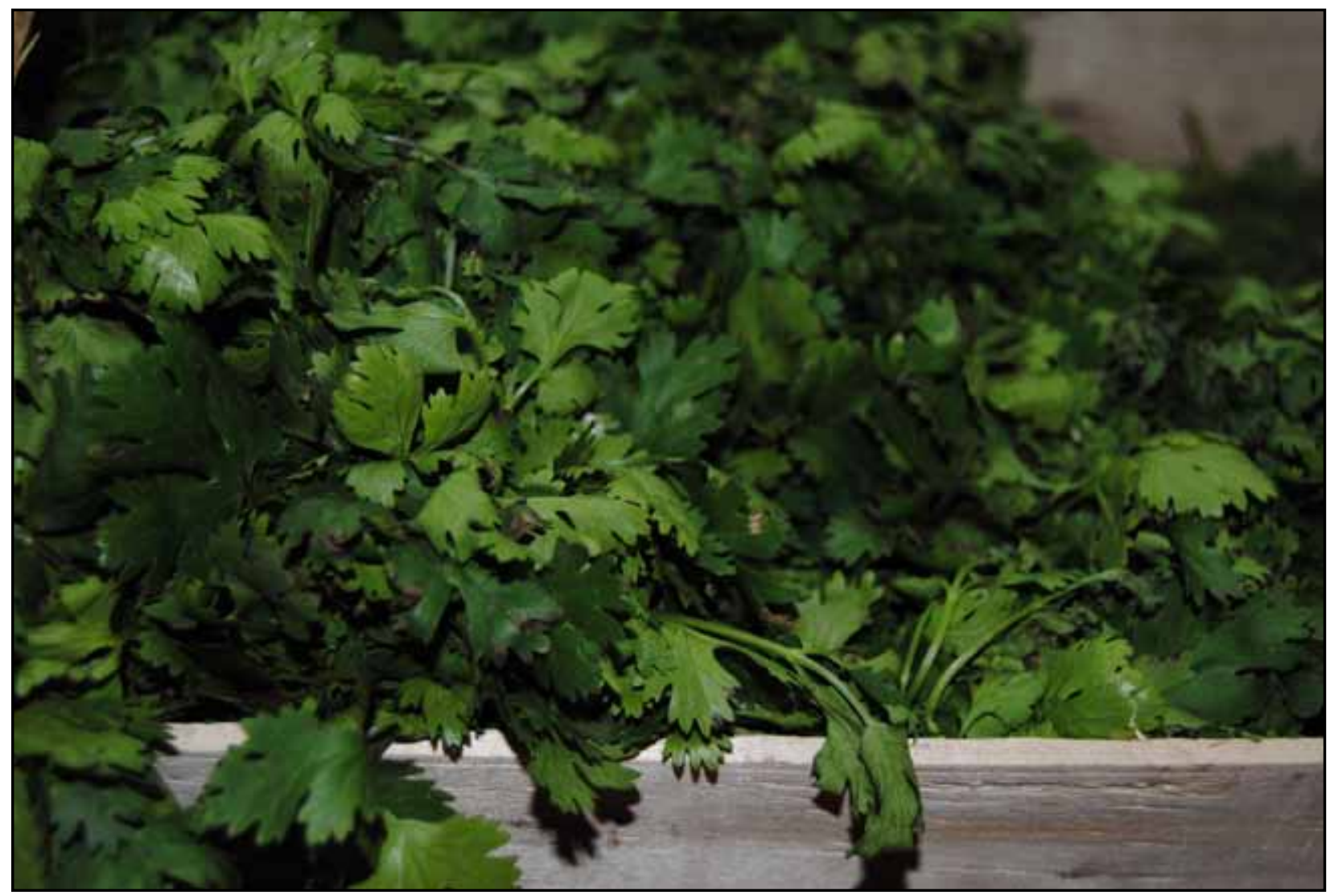

Figure 6. Coriandrum sativum L., sold at Piazza Vittorio Emanuele located in the Esquilino area of Rome, is an essential aromatic herb used for many traditional Peruvian dishes, i.e., the most well-known ceviche. 

assessment through images

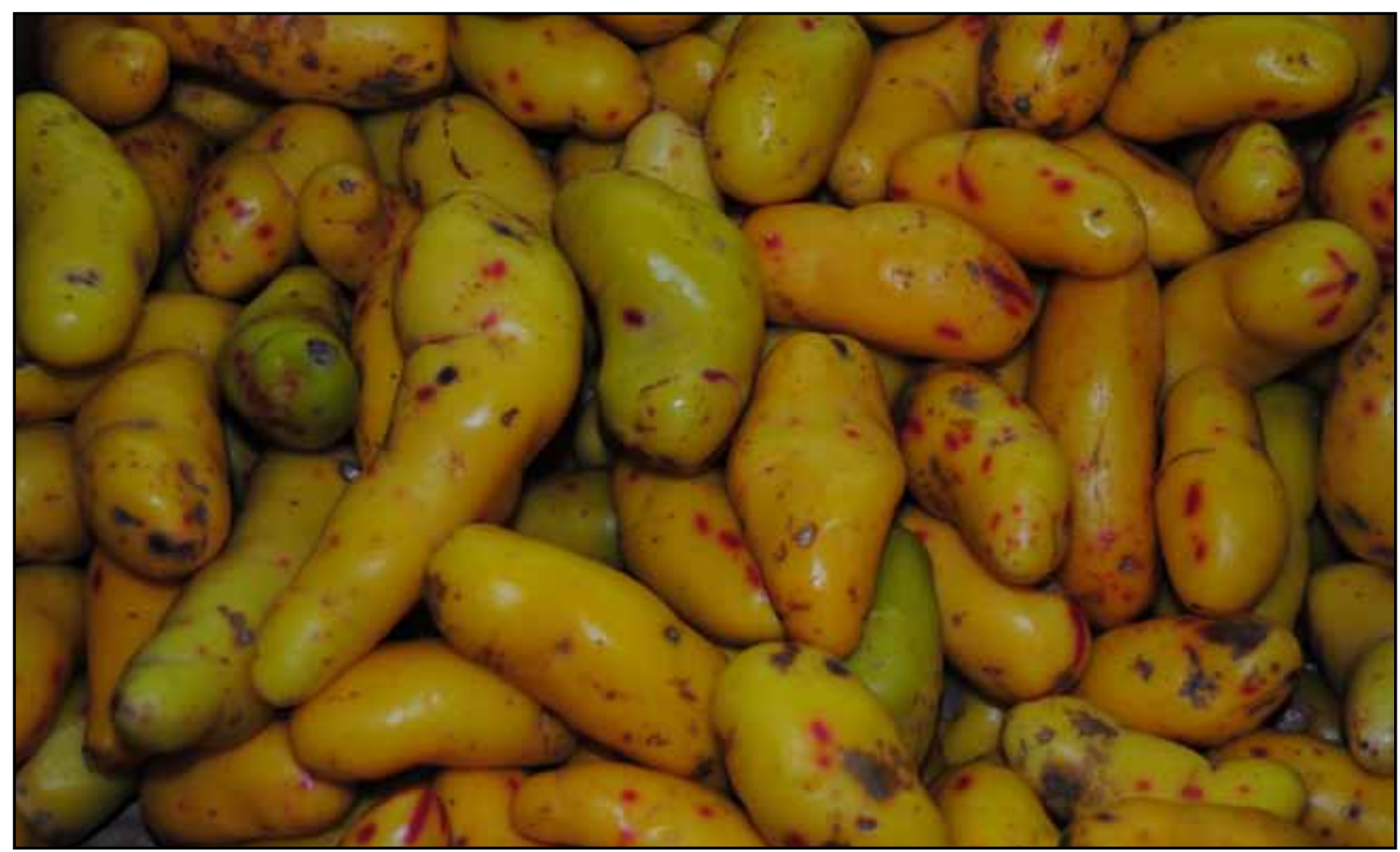

Figure 7. Peruvian food tuber, Ullucus tuberosus Caldas sold at a Latin American store. Many vegetables, fruits, herbs and aromatic plants are imported from Peru.

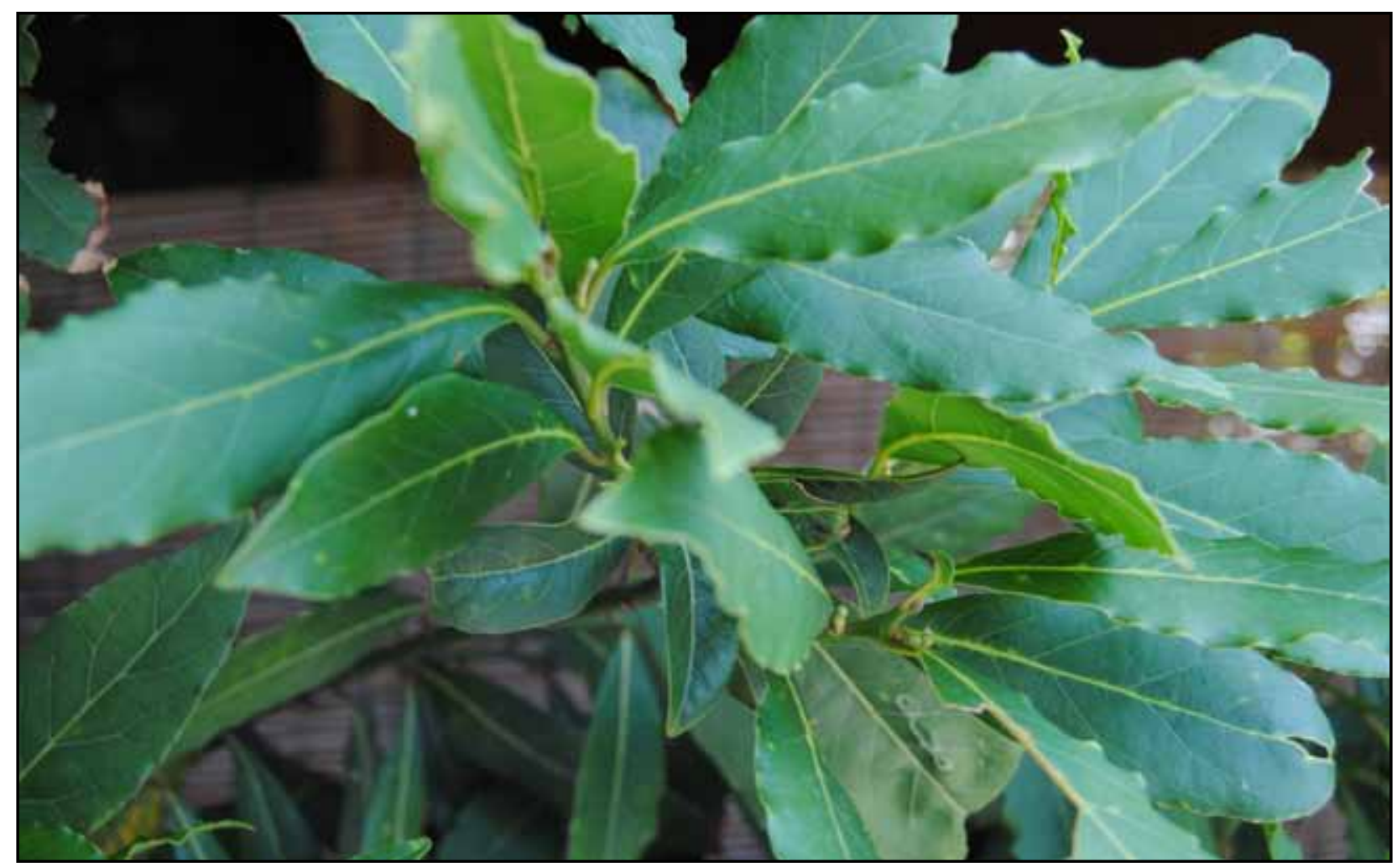

Figure 8. Laurus nobilis L. This plant in Rome is widely cultivated for ornamental purposes: in city parks, in private gardens and along the streets. It is important to Peruvians as well. 


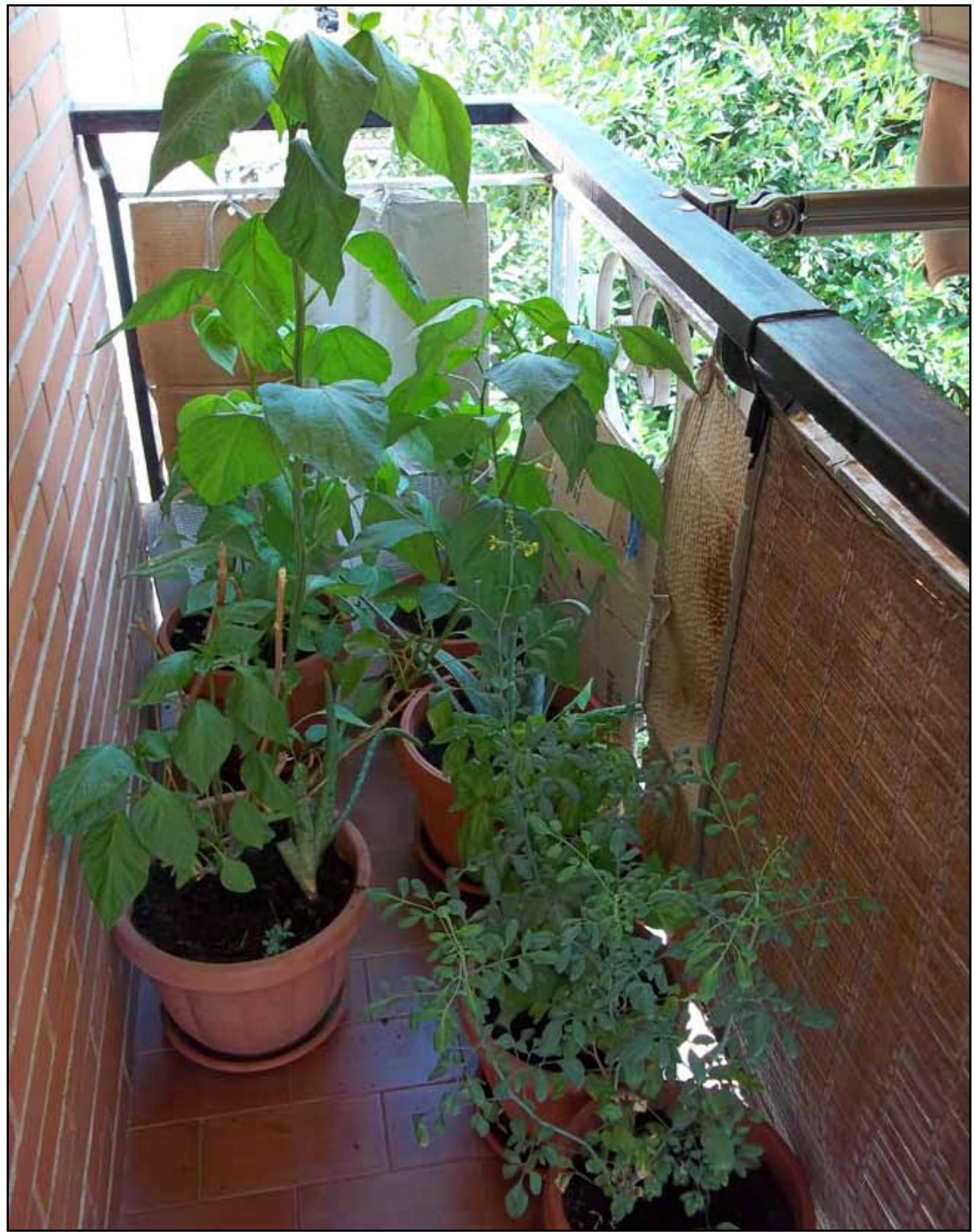

Figure 9. A small "homegarden" of Peruvian plants cultivated in Rome, Italy. The image shows the plants: Aloe vera (L.) Burm. f. (sabilla)., Ruta graveolens L. (ruda)., Ocimum basilicum L. (basilico), and Capsicum pubescens Ruiz \& Pav. (aji rocoto). 


\section{Matos-Soto and Savo - The Transplanted Peruvian Culture in Rome: An assessment through images}

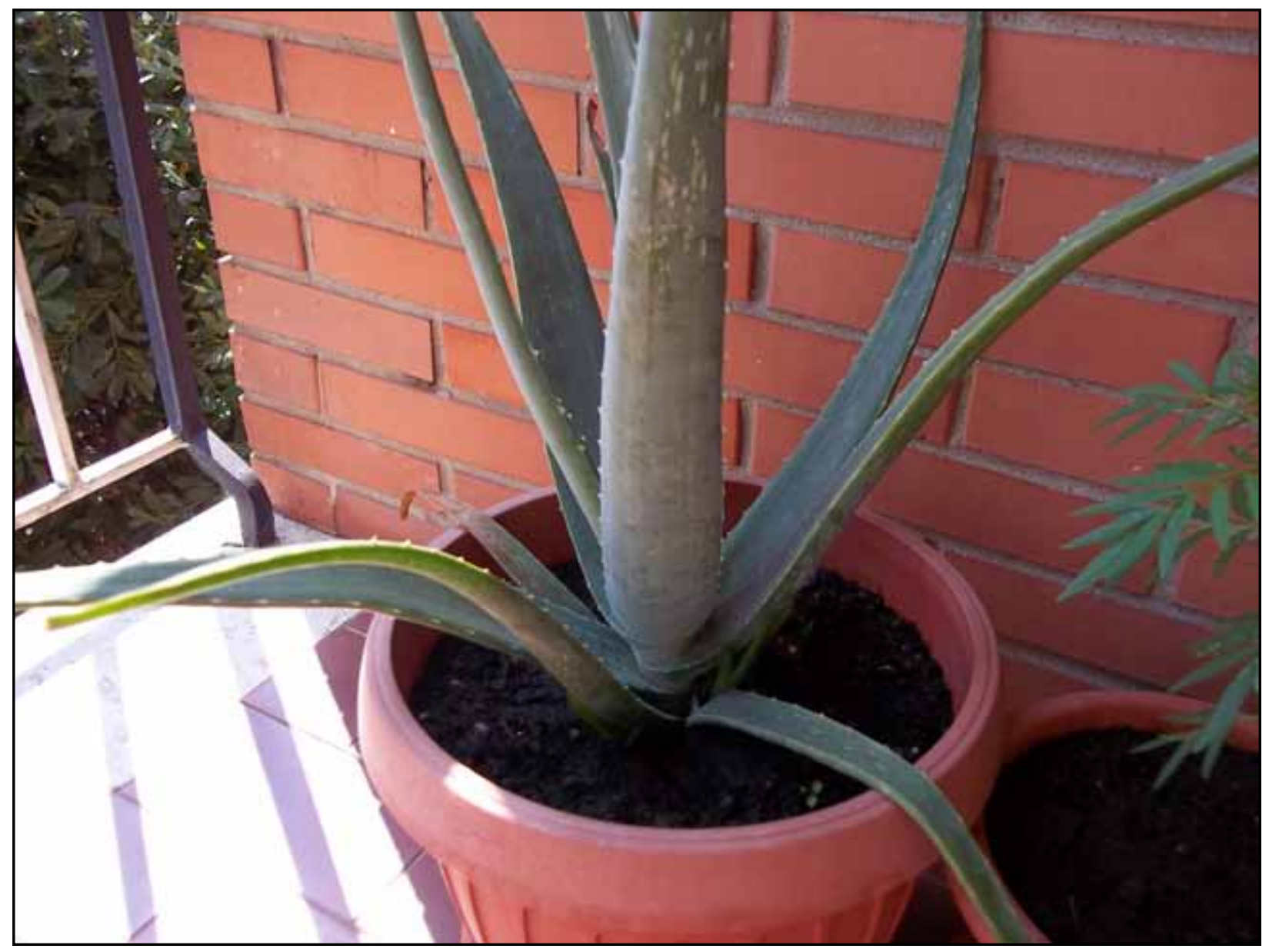

Figure 10. A specimen of Aloe vera (L.) Burm. f. (sabilla) found cultivated on an informant's balcony in Rome, Italy.

ick et al. 2011). The most cited food plants (the first five) were: S. tuberosum, Zea mays L., Coriandrum sativum L., O. basilicum, and $L$. nobilis. When a Peruvian informant was asked why certain plants are important, she explained that "These are the foods (maize and papas) of our ancestors, the Incas used them and it has been that way for years." These culturally important plants hold significance and are predicted to be the plants that the Peruvian people seek to protect, cultivate and if possible, import as well.

Peruvians try to keep the transplanted culture as authentic as possible, finding innovative ways to obtain plants that are missing from their food recipes, because what is more important to them is the fact that they are able to practice their culture (Figure 11). For example they incorporate local varieties of potatoes, tomatoes or peppers in their recipes, whereas in their home country they stated that there are many different ones, some of which are specifically used for certain recipes. Although this is rarely the case for medicinal preparations, they are usually held to be more important culturally (Bussmann \& Sharon 2006, Vandebrock et al. 2004), as well as ingredient replacements could lead to unpredictable or harmful results. In some locations where the interviews were carried out, there were plants of $A$. vera (since it is used as ornamental in many parts of Italy) and informants did not confidently recognize and use the plant, because of the new surrounding environment.

E. coca has a very strong contemporary and historical importance in Peru (Ceuterick et al. 2011, Stolberg 2011). It was mentioned by $1 / 3$ of informants as one of Peru's most important plants. However, in Italy it is not possible to cultivate or use this plant (it is possible to purchase only the mate de coca). This may be the most explicative example of an abandonment of a culturally important use.

In order to draw conclusions on the maintenance or substitution of uses of plant species from Peru a comparison was made between informants' data and literature from Peru. For instance, Melissa officinalis L. was mentioned by two separate informants. One informant stated that $M$. officinalis was "good for stomach pain and is a relaxant" and the other solely described its preparation as a relaxant, and stated an equivalent replacement was $M$. cham- 


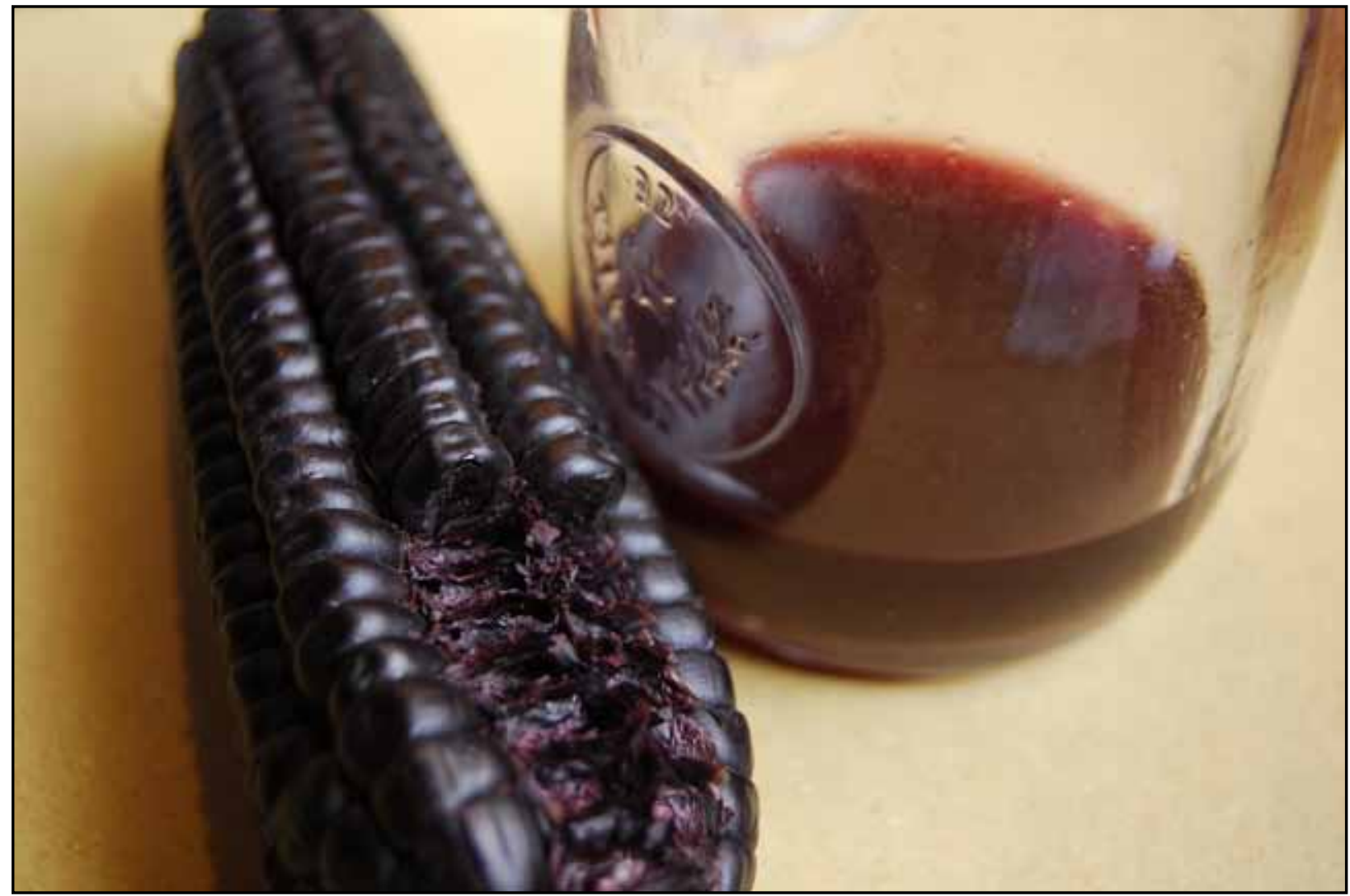

Figure 11. Chicha morada: this beverage, made by purple maize (choclo morado), is boiled with pineapple rind, cinnamon, and cloves. It is served in Peruvian restaurants in Rome, but it is a culturally important refreshing beverage in Peru that is also considered medicinal. It is sweet, juicy and aromatic (tastes like "spice").

omilla. In Peru, the leaves of $M$. officinalis are used as a sedative and hypotensive (Hammond et al. 1998), to relieve disorders like asthma, cramps, headache, etc. (Rehecho et al. 2011) providing valid reason that the use of $M$. officinalis is still retained and no new uses have emerged, although $M$. chamomilla was noted as a replacement. Another example is the maintenance of the use of $R$. graveolens to relieve menstrual pains (Rehecho et al. 2011); this plant seems to be used also as an abortive in Peru (Bussmann \& Glenn 2010), but not in Italy.

Here we can assume that we are recording the most important species, some may be replaced by different varieties, but they are essential aspects of the Peruvian culture. Also there were eight food and medicinal plants that were remembered by informants that were used in Peru that they stated were not found in Rome or Italy [of these plants we only know the common names: nolgar, mateco, quinoa (which is probably Chenopodium quinoa Willd.), sancha de piedras, chillimola, marko (or marco), panca and sachaenche]. Single informants cited a higher number of unavailable plants but some of these plants were available to other informants. We made this assumption with a comparison of the vernacular names.
We noticed a trend that long-term Peruvians that have lived in Rome for longer periods (20+) tend to use plants that are easily retrieved in standard supermarkets or are globally used (e.g., M. x piperita, A. vera), which are still part of their culture but are more affordable.

The community as a whole tries to find innovative ways for substituting missing elements, with the plant species that resemble their culturally important species. Yet, because of difficulty in properly performing traditions and finding the necessary items, this leads to the abandonment of certain traditions or uses. Plantago linearis H.B.K. is a very rare plant to find in Italy, the sole informant that cultivated it in her balcony mentioned that "every Peruvian that visits wants to have a plant". The aromatic leaves of $P$. linearis are mixed and simmered with $C$. baccatum var. pendulum, garlic, milk, oil and salt, then consumed over boiled potatoes. Since $P$. linearis is so rare to find, many people in the community no longer prepare this dish.

Few ethnobotanical uses from the Italian traditions have been incorporated in the Peruvian customs (Figure 12). An example mentioned is the habit of consuming oatmeal broth with cinnamon that some elderly Italians partake 


\section{Matos-Soto and Savo - The Transplanted Peruvian Culture in Rome: An assessment through images}

in. This preparation is an Italian tradition for soothing the stomach. It is made by boiling Avena sativa L. and Cinnamomum verum J. Presl. This was recorded by an informant who had gastrointestinal ulcers. She started to prepare this beverage after learning about it from an Italian friend.

Finally, we noticed that young people who were occasionally present during interviews were not very interested in the topic and seem to have limited ethnobotanical knowledge.

The purpose of this photo essay was to express how proud and compassionate the people of Peru are about their culture (Figure 13; Figure 14); it is an aspect of the culture that could not be taken in account quantitatively.

\section{Conclusion}

Cross-cultural adaptation is a diverse and complex phenomenon, which may consist of incorporation, rejection or evolution of ethnobotanical uses of plants by migrants.
Despite the difficulties in obtaining certain plants our $\mathrm{Pe}$ ruvian informants demonstrated the willingness to keep their knowledge by constantly informing others in the community of ways to continue making medicinal preparations. Also, they seemed to be reluctant to comply with multicultural fusion, thus they attempt to adhere to a national identity and try to conserve their intrinsic cultural elements as much as they can. However, many constraints (importing regulations, high prices) limit the potential of the ethnobotanical practices and uses to be retained outside of Peru.

\section{Acknowledgements}

We are grateful to all the informants who participate in this research and shared with us their knowledge on plant uses. Also we would like to thank the following people for their support: Professor Giulia Caneva, Professor Giorgio Turri, Jason Hamidi and Michael Peterson.

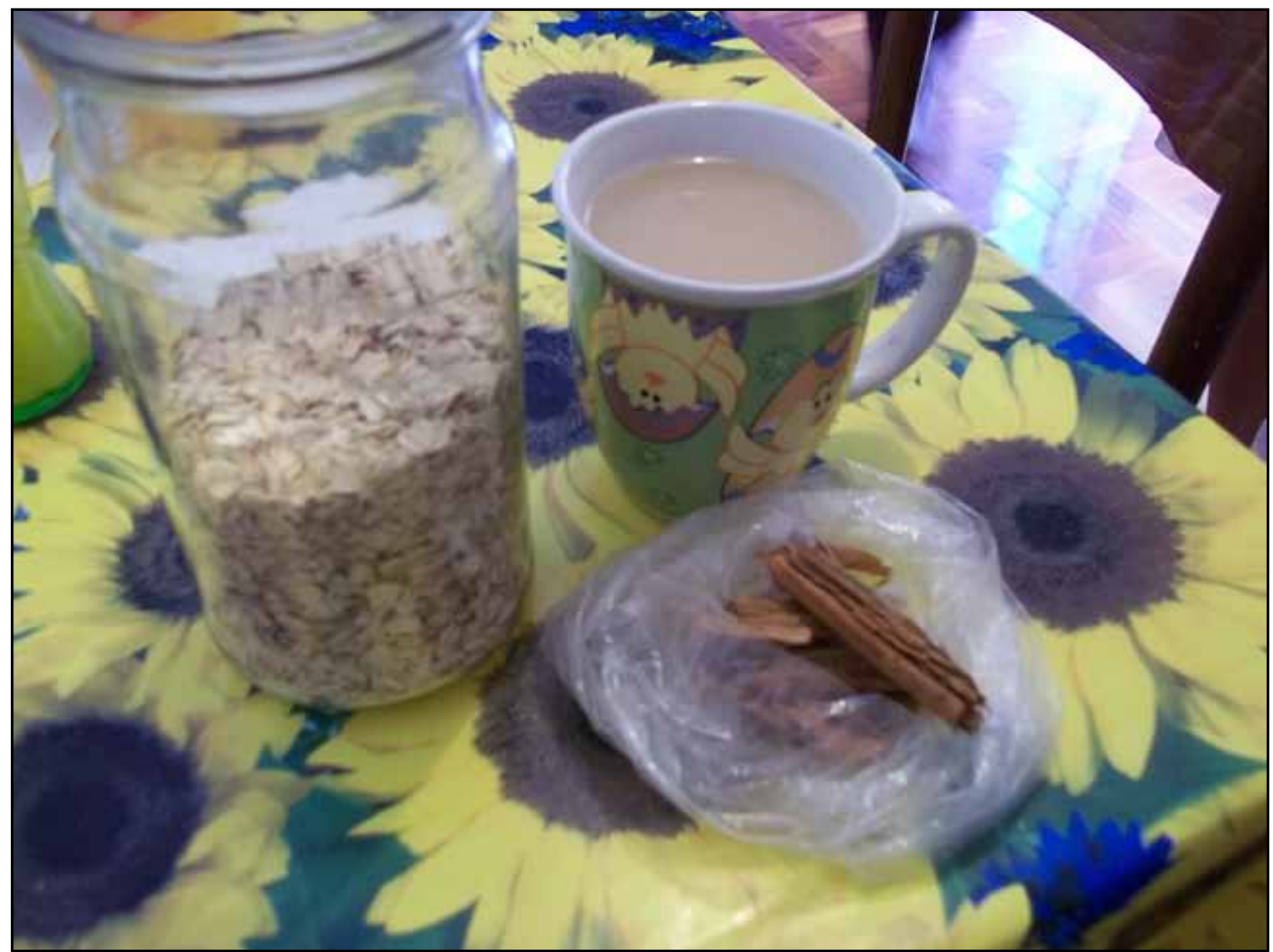

Figure 12. The preparation of a tea made by boiling Avena sativa L. and cinnamon that is strained leaving the sweet broth. It is to be drank every day, the informant mentioned that it was an Italian tradition. 


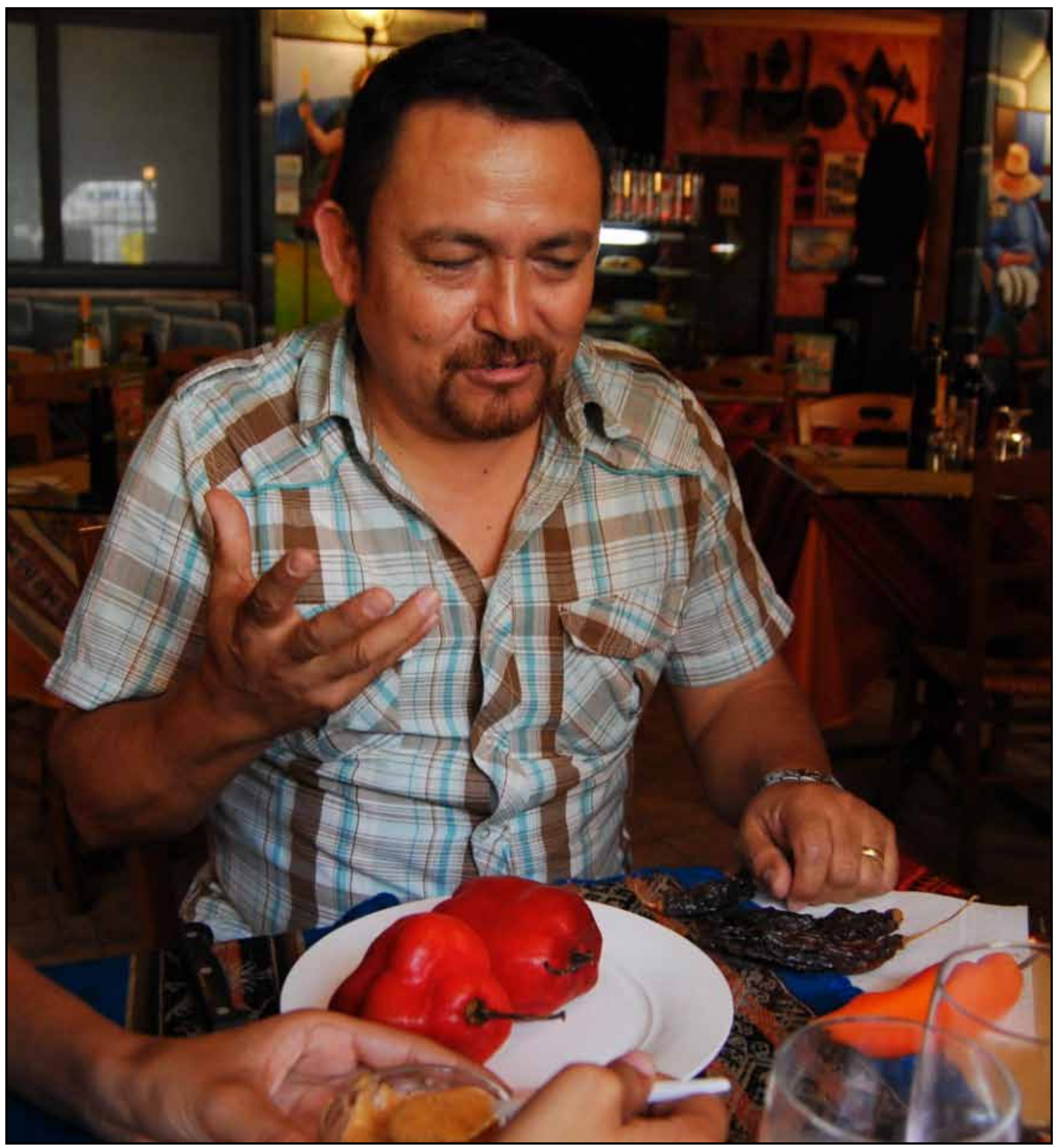

Figure 13. This informant went to the back of his restaurant and came back with a bag full of food plants. He took the time to explain each single plant and he was proud to describe his culture.

\section{Literature Cited}

Bussmann, W.R. \& A. Glenn. 2010. Medicinal plants used in Northern Peru for reproductive problems and female health. Journal of Ethnobiology and Ethnomedicine 6:30.

Bussmann, W.R. \& D. Sharon. 2006.Traditional medicinal plant use in Northern Peru: Tracking two thousand years of healing culture. Journal of Ethnobiology and Ethnomedicine 2:47.

Castillo, J.J. 2009. Snowball Sampling. www.experiment-resources.com/snowballsampling.

html\#ixzz1S5OuGVMH] 24 June 2011.

Ceuterick, M., I. Vandebroek \& A. Pieroni. 2011. Resilience of Andean urban ethnobotanies: A comparison of 


\section{Matos-Soto and Savo - The Transplanted Peruvian Culture in Rome: An assessment through images}

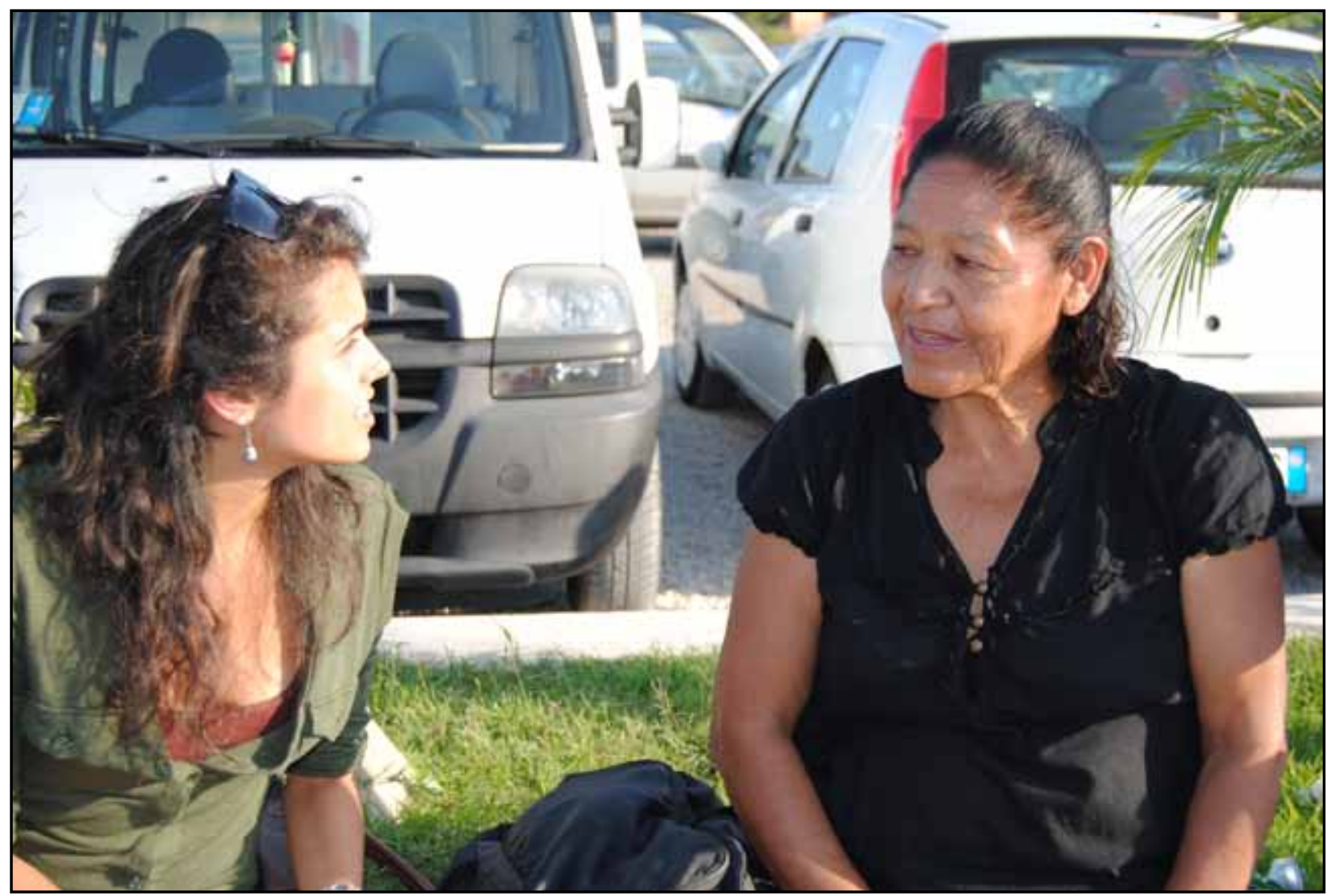

Figure 14. This lady showed us Peruvian plants that she was carrying in her bags. She stated that she does not trust Western medicine and that she cures herself only with Peruvian medicinal plants.

medicinal plant use among Bolivian and Peruvian migrants in the United Kingdom and in their countries of origin. Journal of Ethnopharmacology 136:27-54.

Ceuterick, M., I. Vandebroek, B. Torry \& A. Pieroni. 2008. Cross-cultural adaptation in urban ethnobotany: the Colombian folk pharmacopoeia in London. Journal of Ethnopharmacology 120:342-359.

Duke, J.A. \& R.V. Martinez. 1994. Amazonian Ethnobotanical Dictionary. CRC press, Ann Arbor, Michigan.

Green, G., H. Bradby, A. Chan \& M. Lee. 2006. "We are not completely Westernised": Dual medical systems and pathways to health care among Chinese migrant women in England. Social Science and Medicine 62:1498-1507.

Hammond, G.B., I.D. Fernandez, L.F. Villegas \& A.J. Vaisberg.1998. A survey of traditional medicinal plants from the Callejo'n de Huaylas, Department of Ancash, Peru. Journal of Ethnopharmacology 61:17-30.

Hudson, R.A. 1992. Editor of Peru: A country study. GPO for the Library of Congress, Washington, DC.
ISE. 2006. International Society of Ethnobiology Code of Ethics (with 2008 Additions). www.ethnobiology.net/ethics.php] 28 June 2011.

ISTAT. 2010. The Foreign Population Resident in Italy. http://en.istat.it/popolazione/stranieri/ 13 June 2011.

Johnson, L.G. \& K. Sabin. 2010 Sampling hard-to-reach populations with respondent driven sampling. Methodological Innovations 5(2):38-39.

Maas, P. \& L. Westra. 1993. Neotropical Plant Families. A concise guide to families of vascular plants in the neotropics. Koeltz Scientific Books, Koenigstein.

Maxia, A., M.C. Lancioni, A.N. Balia, R. Alborghetti, A. Pieroni \& M.C. Loi. 2008. Medical ethnobotany of the Tabarkins, a northern Italian (Ligurian) minority in southwestern Sardinia. Genetic Resources and Crop Evolution 55:911-924.

McClatchey, W.C., L.X. Gollin \& S.R. Rakotonandrasana. 2005. Ethnobotanical Reseach at Analalava, Madagascar: A photo essay. Ethnobotany Research \& Applications 3:391-403. 
Nebel, S., A. Pieroni \& H. Heinrich. 2006. Ta chòrta: wild edible greens used in the Graecanic area in Calabria, Southern Italy. Appetite 47(3): 333-342.

Pieroni, A. 2005. Traditional pharmacopoeias and medicines among Albanians and Italians in southern Italy: a comparison. Journal of Ethnopharmacology 101(13):258-270.

Pieroni, A., C. Nebel, C.L. Quave, H. Münz \& M. Heinrich. 2002a. Ethnopharmacology of liakra, traditional weedy vegetables of the Arbëreshë of the Vulture area in southern Italy. Journal of Ethnopharmacology 81:165-185.

Pieroni, A, C.L. Quave, S. Nebel \& H. Heinrich. 2002b. Ethnopharmacy of ethnic Albanians (Arbëreshë) in northern Basilicata (southern Italy). Fitoterapia 73:217-241.

Pieroni, A. \& I. Vandebroek. 2007. Traveling Cultures, Plants and Medicine; The ethnobiology and ethnopharmacy of migrations. Berghahn Books, New York, New York.

Pignatti, S. 2003. Flora d'Italia. Volumes I-III. Edagricole, Bologna, Italy.

Rehecho, S., I. Uriarte-Pueyo, J. Calvo, L.A. Vivas \& M.I. Calvo. 2011. Ethnopharmacological survey of medicinal plants in Nor-Yauyos, a part of the Landscape Reserve Nor-Yauyos-Cochas, Peru. Journal of Ethnopharmacology 133:75-85.

Smith, N., S. Mori, A. Henderson, D. Stevenson \& S. Heald. 2004. Flowering Plants of the Neotropics. Princeton University Press, Princeton, New Jersey.
Stolberg, V.B. 2011. The use of coca: Prehistory, History, and ethnography. Journal of Ethnicity in Substance Abuse 10(2):26-146.

ThePlantList.org. 2011. A working list of all plant species. www.theplantlist.org. 01 August 2011.

Thiers, B. 2011. Index Herbariorum: A global directory of public herbaria and associated staff. New York Botanical Garden's Virtual Herbarium. http://sweetgum.nybg.org/ih/.

Tropicos.org. 2011. Missouri Botanical Garden. www.tropicos.org. 01 August 2011.

Van Andel, P. W. 2010. Why Surinamese migrants in the Netherlands continue to use medicinal herbs from their home country. Journal of Ethnopharmacology 127:694701.

Vandebrock, I., J. Calewaert, S. De Jonckheere, S. Sanca, L. Semo, P. Van Damme, L. Van Puyvelde \& N. De Kimpe. 2004. Use of medicinal plants and pharmaceuticals by indigenous communities in the Bolivian Andes and Amazon. Bulletin World Health Organization 82(4):243-250.

Walters, S.M., J.C.M. Alexander, P.G. Barnes, F.M. Bennell, J.J. Bos, A. Brady, C.D. Brickell, E.J. Campbell, C.J. Couer, J. Cullen, S.J.M. Droop, P.S. Green, C. GreyWilson, V.H. Heywood, P.-M. Jorgensen, S.L. Jury, S.G. Knees, A.C. Leslie, V.A. Mathews, N.K.B. Robson, D.O. Wijnands \& P.F. Yeo. 1986-2000. Editors of The European Garden Flora. Cambridge University Press, Cambridge, United Kingdom.

Walter, M.N. \& E.J.N. Fridman. 2004. Shamanism. ABC CLIO Publications, Santa Barbara, California. 